Polgári Szemle, 16. évf. 4-6. szám, 2020, 285-297., DOI: 10.24307/psz.2020.1021

Keller Veronika - Printz-Markó Erzsébet

\title{
A marketinginnovációk szerepe a termál- és gyógyfürdók (spa) szektorában
}

\author{
The Role of Marketing Innovations \\ in the Spa Sector
}

\section{ÖSSZEFOGLALÁS}

Napjaink egyik legdinamikusabban fejlôdő turisztikai ágazata az egészségturizmus, ahol az innovációnak egyre nagyobb jelentôsége van. Kutatómunkánk középpontjában az egészségturizmus wellness- és rekreációs szolgáltatásokhoz kapcsolódó része áll. Egy online kvantitatív kutatás keretében vizsgáltuk a wellness-szolgáltatásokat igénybe vevôk innovativitását. A faktorelemzés eredménye alapján az innovativitásnak három területét azonosítottuk: a marketingújításokra való fogékonyságot, az újdonságokra való fogékonyságot és az árinnovációkat. Általánosságban elmondható, hogy a fürdôvendégek kevésbé innovatívak, különösen igaz ez az idôsebb (55 év feletti) vendégekre és az idôsebb egyedülállókra. A fiatalok és a kisgyerekes családok, illetve a középkorú párok számára fontos az innováció, a szolgáltatás kiválasztásakor döntô szempont lehet számukra akár a termék vagy szolgáltatás területén nyújtott újítások, vagy a digitális innovációk. Az árak kétségkívül jelentốs vonzerôvel bírnak. A hazai fürdôk törekedhetnének az ár típusú promóciók változatos alkalmazására, amenynyiben versenyelônyre kívánnak szert tenni az egészségturizmus piacán.

Journal of Economic Literature (JEL) kódok: L83, M31, O30

Kulcsszavak: egészségturizmus, innováció, innovativitás, wellness

Summary

Health tourism is one of the most rapidly developing fields, which assigns an increasing role to innovation. This paper focuses

Dr. Keller Veronika egyetemi docens, Széchenyi István Egyetem, Kautz Gyula Gazdaságtudományi Kar, Marketing és Menedzsment Tanszék (kellerv@sze.hu), Dr. Printz-Markó Erzsébet egyetemi adjunktus, Széchenyi István Egyetem, Kautz Gyula Gazdaságtudományi Kar, Turizmus Tanszék (printz-marko.erzsebet@sze.hu). 


\section{Tudományos múhely}

on wellness and recreation services. The authors conducted an online quantitative study to reveal the innovativeness of bath's guests. The factor analysis identified three fields of innovation: responsiveness to marketing innovation, susceptibility to new services and price innovation. In general, it can be stated that Hungarian spa visitors are not really open to innovation, especially the elderly guests (above 55) and elderly single guests. However, marketing innovations, mainly service and product innovations, and digital innovations may have a predominant impact on younger generations and young couples with small children or middle-aged couples with children over 10. Price innovations are attractive for Hungarian people. Hungarian spas and wellness establishments should adopt price promotions in a variable way to obtain competitive advantage in the health tourism market.

Journal of Economic Literature (JEL) codes: L83, M31, O30

Keywords: health tourism, innovation, innovativeness, wellness

\section{Bevezetés}

Mai felgyorsult életünkben a magán- és a szakmai életben való helytálláshoz fontos a mentális és fizikai egészségünk megórzése, karbantartása. Hosszú távú befektetésnek tekinthetố az egészségmegôrzésre, prevencióra fordított kiadás. A Global Wellness Institute (GWI) statisztikai mutatói alapján a wellnesspiac éves növekedési üteme $6,5 \%$ volt 2015 és 2017 között. A spapiac (egészségturizmus = gyógy- és wellnessturizmus) értéke 2022-re várhatóan 154,6 milliárd dollár lesz. A termálvizekre és fürdôkre épüló ágának fejlôdési pályája is dinamikus. Az egészséges életmódnak, az egyre tudatosabb, prevenciót elôtérbe helyezố látásmódnak, a bôvülố rehabilitációs lehetôségeknek köszönhetôen emelkedik az ágazat szolgáltatásait igénybe vevốk aránya (Global Wellness Institute, 2018).
Magyarországon a hazai és a külföldi vendégek körében Budapest mellett a fürdôtelepülések a legnépszerúbbek. 2018ban közel harmincmillió látogatója volt a hazai fürdôknek, mely 64,2 milliárd forint árbevételt jelentett (MTI, 2019a). Hévíz, Hajdúszoboszló, Bük, Zalakaros vagy Sárvár az elmúlt 12 évben a vendégéjszakák száma tekintetében a leglátogatottabb tíz magyarországi település között szerepelt. Budapest mellett Hévíz az egyetlen olyan településünk, ahol a kereskedelmi szálláshelyeken eltöltött vendégéjszakák száma 2016 óta folyamatosan meghaladja az évenkénti egymilliót (MTI, 2020). A Magyar Fürdőszövetség 2017-2018. évi összefoglalója alapján elmondható, hogy a vizsgált idôszakban a fürdôszolgáltatás nettó árbevétele 7,5\%-kal emelkedett, 2019. évben 16\%-os volt a növekedés (Turizmus.com, 2019; Magyar Fürdôszövetség, 2019a).

A Global Wellness Institute kutatásai alapján az ágazat legújabb trendei közé az alábbiak tartoznak:

- tudatosabb életmód a biológiai szervóra szerint, ugyanis az étkezések biológiai óra szerinti idôzítése jelentôsen nagyobb súlycsökkenést és más egészségügyi elônyöket eredményezhet, megmutatja a testben lezajló folyamatokat, így segítségével meghatározható, mikor a legnagyobb hatásfokú az edzés vagy a regenerálódás;

- a 60 év felettiek „felfedezése” és megszólítása, mivel radikális különbségeket mutatnak elôdeikhez képest, egyfajta prémiumkategóriát jelentenek egészségtudatos életmódjuk következtében;

- J-wellness, azaz a japán wellness mint követendô példa a hagyományok és az innovatív technológiák összeházasítása révén, amely magában foglalja a szociális kapcsolatok ápolását, az új technológiák és fejlesztések alkalmazását, például a bőrápolás területén; a természetközeliség élményét adó erdei meditációk elvégzését; kolostorba történố elvonulást; az olimpiai rendezvény hatására a sportolás beépítését a napi rutinba; 


\section{Tudományos múhely}

- mentális wellness a technológia segítségével, a mindig elérhetô és rendelkezésre álló virtuális orvosi tanácsadással, olyan hordható és hordozható eszközök segítségével, mint például az érzelemérzékelô karkötố beépített bioszenzorokkal, amely egész nap figyeli a felhasználó fiziológiai jeleit;

- az energiagyógyászat térnyerése, az orvosok és a wellness-szakemberek nyitottsága az elektromágnes-, fény- és hangterápiák iránt;

- vallási elemek beépítése a mozgásterápiába az életmód és a hit integrációjának köszönhetôen, például az úgynevezett Soul Care program keretében a nyújtás és a funkcionális mozgás a rózsafüzér imáival párosul (Global Wellness Institute, 2020).

A turisztikai piac szerteágazó és egyre élesedô versenyében az innovatív desztinációk képesek helytállni (Spiegler, 2009). Ennek értelmében központi elemet jelent az olyan új, innovatív, minôségi, célcsoport-orientált és piacképes kínálat kialakítása, amelynek köszönhetốn a szolgáltatók és szolgáltatások homogén, a piacon beazonosítható termékként, márkaként tudnak megjelenni (Gonda-Spiegler, 2012). A turisztikai szolgáltatások piacképességének egyik alappillérét jelenti az innovációra, a folyamatos megújulásra való képesség (Magyar Turizmus Zrt., 2009).

A fentiek értelmében a szolgáltatótól elvártnak tekinthetố innováció kapcsán fogalmazódtak meg bennünk olyan kutatási kérdések, mint például, hogy a felvevôpiac, azaz a kereslet milyen mértékú és milyen jellegú innovációra nyitott. Jelen tanulmányban tömören összevetettük a kapcsolódó szakirodalmat, majd ismertetjük online kérdốives kutatásunk ( $\mathrm{n}=249$ fô) eredményeit, központi szerepet adva a szolgáltatást igénybe vevốk innovatitásának. Kutatási eredményeink révén, faktorelemzéssel azonosítjuk az innovativitás területeit, különös tekintettel az egészségturizmus célcsoportjaira. Következtetéseink megfogalmazása után kitérünk a kutatás korlátjaira, jövôbeli lehetséges irányaira.
Reményeink szerint jelen tanulmány egyfajta innovációtervezố segédletként szolgálhat a hazai fürdôlétesítményeknek, és alapját, szerves részét képezheti a Magyar Fürdôinnovációs Díjért benyújtandó pályázataiknak.

\section{SZAKIRODALMI ÖSSZEFOGLALÓ}

Kutatásunkat meghatározó témakörök az innováció, a marketing és az egészségturizmus spektrumába tartozó fürdôturizmus. Az utóbbi kettôt kutatómunkánk összetettségéból fakadóan komplexen közelítjük meg fürdômarketing címszó alatt. A kapcsolódó nemzetközi és a hazai szakirodalom feldolgozásához szakkönyveket, könyvfejezeteket, szakmai folyóiratokat, tudományos publikációkat, szakmai cikkeket és a turizmus témájában megjelenô napi hírleveleket használtunk fel.

Az innováció terminológiájának meghatározása Schumpeter (1939) nevéhez fúzôdik, aki szerint az innováció új termék létrehozását, új termelési eljárás bevezetését, új piacokra történố nyitást, új nyersanyagforrásokat, új ipari szervezet létrehozását jelenti. Az Oslo Kézikönyvben elfogadottak szerint az innováció úgy határozható meg, mint új marketingmódszer, új szervezési-szervezeti módszer bevezetése az üzleti gyakorlatban, munkahelyi szervezetben, a külsô kapcsolatokban (Katona, 2006). Ezek egyben az innovációk típusait is meghatározzák. Jelen kutatás a marketinginnováció területéhez kapcsolódik. A turizmus területén a margetinginnovációkkal foglalkozik írásában többek között Haywood (1990), Walle (1998), Middleton és Hawkins (1998), Amoiradis (2019), Piskóti (2007), Horváth és Bauer (2016), Darabos és társai (2018), Happ és Keller (2020).

A termál- és/vagy gyógyvízzel rendelkezô fürdôlétesítmények, azaz a spaszektor (Smith-Puczkó, 2010) innovációinak elemzése során Vazquez-Illá Navarro (2014) arra a következtetésre jutott, hogy az alapvetô innovációk együttmúködések keretében, klaszterek égisze alatt valósulnak meg. 


\section{Tudományos múhely}

A szolgáltatók figyelemmel kísérik a környezet változásait, és az újítások generátorai a fogyasztók, valamint az új piaci szereplók.

A fürdőturizmus kapcsán Lőrincz és kutatótársai három kiemelt erôsítendô területet határoztak meg: az innovatív termékek kialakítása (gyógyvízalapú termékek, gyógyszerek, orvosi múszerek), a jó megoldások alkalmazása (geotermikus energia hasznosítása) és a tudástranszfer (Lórincz et al., 2014). Ruszinkó a helyspecifikus természetes gyógytényezókön alapuló kínálat kialakítását tekinti a profilmeghatározás legfóbb elemének, amelyre célcsoport-specifikus egészségmegôrzô, gyógyító és rehabilitációs szolgáltatások épülnek (Turizmus Panoráma Bulletin, 2015). Könnyid is a specializáció erôsítése mellett érvel. Indokoltnak tekinti a tematikus és egyedi szolgáltatások létrehozását (MTI, 2019b). Várhelyi (2012) a marketingmunka jelentôségét hangsúlyozza, különös tekintettel a foglalási és promóciós rendszerek fejlesztésére. Szabó (2015) kutatási eredményei alapján egy olyan tudatos marketingmunkát ajánl, amely elsôsorban a gyógyvízzel kezelhetô betegségtudatra épít, és kommunikációjában a nôkre koncentrál.
A fürdőmarketing szempontjából fontos megemlíteni, hogy a Global Wellness Institute a termál- és gyógyfürdô-létesítményeket három csoportba sorolja. A múködési profil alapján megkülönbözteti a wellness, a rekreációs és a terápiás/gyógyászati célú fürdôket. A hazai jellemzókkel összehangolt modellt tartalmazza az 1. táblázat.

A hazai egészségturizmus-piac szegmentációját elsôként Budai és Székács határozta meg. Szempontrendszerük alappillérét a szolgáltatás jellege és az életkor jelenti (Budai-Székács, 2004). A trendeket figyelembe véve Árpási két további célcsoporttal egészítette ki (fiatal párok kisgyermekkel, nagyszülók unokákkal) ezt a korosztály-szolgáltatási mátrixot (Árpási, 2012) (2. táblázat).

Összességében az egészségturizmus fogyasztói célcsoportja lehet az egészséges és a beteg ember (Rátz, 2004). Kutatásunk szempontjából a kilenc célcsoportból az alábbi hét célcsoport számít lényegesnek, akik a következóképpen jellemezhetôk:

1. aktív, egészségtudatos fiatalok: gyermek nélküli fiatalok, akik aktív programra, mozgással, sportolással eltölthetố helyre vágynak,

1. táblázat: Termál- és gyógyfürdôk csoportositása

\begin{tabular}{l|l}
\hline \multicolumn{1}{c|}{ Fürdó típusa } & \multicolumn{1}{c}{ Típusjellemzók } \\
\hline Wellness & $\begin{array}{l}\text { Termálvíz, uszodai létesítmények } \\
\text { Termálvízzel rendelkezó akvaparkok }\end{array}$ \\
\hline \multirow{2}{*}{ Rekreáció } & $\begin{array}{l}\text { Termál és gyógyvízzel rendelkezó fürdók és spák } \\
\text { Thalasso terápiás fürdôk }\end{array}$ \\
\hline Gyógyászat, terápia & $\begin{array}{l}\text { Gyógyhelyek } \\
\text { Fürdôszanatóriumok }\end{array}$ \\
\hline
\end{tabular}

Forrás: Saját szerkesztés a Global Wellness Institute, 2018 alapján

2. táblázat: Az egészségturizmus célcsoportjai

\begin{tabular}{|c|c|c|c|}
\hline & Wellness & Rekreáció & Gyógyászat, terápia \\
\hline 18-34 év & aktív, egészségtudatos fiatalok & $\begin{array}{l}\text { szórakozást keresók } \\
\text { fiatal párok kisgyerekkel }\end{array}$ & \multirow{2}{*}{$\begin{array}{l}\text { mútét utáni rehabili- } \\
\text { tációra szorulók }\end{array}$} \\
\hline 35-54 év & egészségmegórző középkorúak & családos középkorúak & \\
\hline $55+$ & egészségtudatos idôsek & nagyszülők unokákkal & gyógyulni vágyók \\
\hline
\end{tabular}

Forrás: Saját szerkesztés Budai-Székács, 2004; Árpási, 2012:17 alapján 


\section{Tudományos múhely}

elsôdleges szempont számukra a szépségápolás és a tartalmas pihenés;

2. egészségmegőrzô középkorúak: általában gyermek nélkül érkeznek, pihenésre, regenerálódásra vágynak;

3. egészségtudatos idôsek: jó egészségi állapotnak örvendô idôsek, akik fontosnak tartják a tartalmas pihenést, a színvonalas kiszolgálást és a kellemes környezetet;

4. szórakozást keresốk: nem a víz miatt keresik fel az adott helyet, de ott-tartózkodásukat meghosszabbítja a településen lévô élményfürdő, csúszdapark;

5. fiatal párok kisgyermekkel: kisgyerekes szülők, akiknek elsôdleges a pihenés, a gyermekbarát szolgáltatások, animációs programok;

6. családos középkorúak: a gyerekek szórakozási lehetôsége és multigenerációs programok alapján választanak fürdóhelyet;

7. nagyszülő́k unokákkal: hasonló az elôzố csoporthoz, hiszen az unokák igényeit tartják szem előtt (Budai-Székács, 2004; Árpási, 2012).

A Magyar Fürdőszövetség hagyományteremtô szándékkal 2019 ôszén indította útjára a Magyar Fürdőinnovációs Díjat. Az innovációs díjért a szakmai szövetség tagjai és pártoló tagjai versenyezhettek (Magyar Fürdôszövetség, 2019b). A meghirdetett kategóriákban az alábbi szolgáltatók kerültek ki nyertesként:

- Innovatív szemléletformálás (marketing és kommunikáció, értékesítés, látogatómenedzsment, oktatás): Hévízgyógyfürdô és Szent András Reumakórház, KinesoLab mozgáslaboratórium;

- Innovatív múszaki-technológiai, üzemeltetési megoldás: Szent Erzsébet Mórahalmi Gyógyfürdô, a termálenergia innovatív hasznosítása a fürdô és a városi közintézmények fútésében;

- Innovatív fürdôszolgáltatás: Zalakarosi Fürdô fejlesztései, mint Gyógycentrum, Fürdô Hotel, Szaunavilág.

A nyeremény egymillió forint értékú marketingtámogatást jelent a Fürdőszövetségtôl. A szakmai szervezet továbbá vállal- ja, hogy a győzteseket elindítja az Európai Fürdôszövetség hasonló pályázatán, amely tartalmazza a nevezési díj befizetését és a pályázat fordítási költségeit (Vámos, 2019).

Fogyasztói oldalról érdemes vizsgálni az egyének innovativitását, nevezetesen, menynyire fogékonyak az újdonságokra. Számos innováció alulról indul, vagyis fogyasztói kezdeményezésre történik. Kutatók több olyan skálát is kidolgoztak, ami a technológiai innovációkra való fogékonyságot, illetve annak fogyasztók által történó fontosságát mérik (Shalev-Morwitz, 2012).

A keresleti és kínálati igényeknek megfelelô, magas minôségú fürdôüzemeltetés és fejlesztés egyfajta „glokális” szemléletet igényel, amely a globális gondolkodást és a lokális cselekvést ötvözi (Printz-Markó, 2007; 2008a). A fenntarthatóság elveit alkalmazó üzemeltetố biztosítja a jogi, a múszaki, a vízminôségi és higiénés körülményeket, a (szak)személyzetet, ismeri a nemzetközi trendeket, a piaci igények kielégítésénél figyelembe veszi a helyi adottságokat és lehetôséget (Németh, 2002; Printz-Markó, 2019). Ezek együttesen adják a fürdôvendégek számára a fürdóélményt. A fürdôélmény alatt az úgynevezett spaélményt értjük, amely a Nemzetközi Spa Szövetség (ISPA) meghatározása szerint a relaxáció (feszültségoldás, stresszcsökkentés), reflexió (meditáció, elmélyült gondolkodás), revitalizáció (újjáéledés, életerô, energia), jókedv (vidámság, szórakozás) együttes átélését jelenti (Rátz, 2004; Gyôri et al., 2013).

\section{Módszertan}

A tanulmány gyakorlati részében több konkrét kutatási kérdést fogalmaztunk meg:

1. Milyen innovációk fontosak a fürdôvendégek számára?

2. Milyen szociodemográfiai ismérvek (életkor, családi életciklus) befolyásolják a fürdôvendégek innovativitását?

3. Befolyásolja az igénybevétel gyakorisága és a kiadások nagysága a vendégek innovativitását? 


\section{Tudományos múhely}

Elsôsorban az innovációk, különös tekintettel a termék-, szolgáltatás- és kommunikációs innovációk szerepére fókuszáltunk a wellness-szolgáltatásokat igénybe vevôk körében. A kutatási kérdések megválaszolásához kvalitatív és kvantitatív módszereket egyaránt használtunk. Az elsô kutatási kérdés kapcsán feltáró kvalitatív kutatást végeztünk, 8 fô, 28 és 65 év közötti nôvel (6 családanya, 2 párkapcsolatban élő, kirepült gyermekkel) készítettünk mélyinterjút a fürdóbe járási szokásaikról. Olyan alanyokat választottunk, akik évente legalább kétszer mennek fürdôbe. Az idôsebb generációhoz tartozó interjúalanyok ennél gyakrabban is igénybe veszik a gyógykezeléseket. A mélyinterjús vizsgálat elsôdleges célja a fürdők által nyújtott innovációk fajtájának feltárása volt, illetve a kutatók (Shalev-Morwitz, 2012) által kifejlesztett skála wellnesspiacra történô adaptálása. Mint kitûnt, mindannyiuk számára fontosak az innovációk, különösen a szolgáltatásokhoz kapcsolódó újdonságok, alapvetôen annak alapján döntik el, hol vegyék igénybe a spaszolgáltatást. A családosok számára az innovatív fürdôszolgáltatások a lényegesek, hogy gyermekeik minél több élményben részesülhessenek.

A kvantitatív kutatás során fóként metrikus skálákat használtunk, de átkódolással voltak olyan esetek, ahol nem metrikus mérési szintû változókat generáltunk.

- 12 attitúdállítást fogalmaztunk meg az innovativitással kapcsolatban, ami elsôsorban a marketinginnovációkhoz kapcsolódik: termék és szolgáltatás; ár (akciók, csomagárak); értékesítés (új értékesítési csatornák); kommunikáció (jelenlét a közösségi médiában, chatbotok alkalmazása, információk megosztása - szájreklám). A skála értékelése az 1: egyáltalán nem fontos; 5: teljes mértékben fontos végpontokkal metrikus skálán történt.

- A szociodemográfiai ismérvek (életkor, lakóhely típusa, gazdasági aktivitás, családi életciklus, anyagi helyzet) nominális skálán mért változók.
- Ezenkívül vizsgáltuk a wellness-szolgáltatások igénybevételének gyakoriságát és az éves kiadások nagyságát, szintén nominális skálán.

- A faktorátlagok (az innovációk területei) az egy faktorba tartozó változókra adott értékek egyszerú számtani átlaga, számított, metrikus változó.

A kutatási kérdések megválaszolásához a primer kutatási módszerek közül az egyszeri keresztmetszeti kutatást választottuk. A tervezett mintanagyság 300 fó volt. Az empirikus kutatás 2019 novemberében zajlott online önkitöltôs kérdôív formájában. A lekérdezésben egyetemi hallgatók vettek részt, akik egy hét alatt gyújtötték be a válaszokat a Facebook közösségi médium segítségével. A kérdőív kitöltésének feltétele volt, hogy az elmúlt egy évben legalább egyszer voltak valamelyik hazai fürdóben, és igénybe vettek valamilyen wellness-, rekreációs vagy gyógyászati szolgáltatást. Végezetül 249 fő́t sikerült elérni, 26,5\%-ban férfiakat, 73,5\%-ban nôket. A válaszadók átlagéletkora 33 év, a szórás meglehetôsen nagy, 12 év, a módusz pedig 22 év. Átkódolással három csoportba soroltuk a válaszadókat: 148 fó fiatal (34 év vagy az alatti; 59,4\%), 74 fó középkorú (35 és 54 év között; 29,7\%) és 27 fó 55 év feletti (10,8\%). A további demográfiai ismérvek alapján az alábbi eloszlást szemlélteti a 3. táblázat.

Az eredmények bemutatása elôtt fontosnak tartjuk kiemelni, hogy a minta nem reprezentatív, nem veszi számba az egészségturizmus teljes célcsoportját, csupán a wellness- és rekreációs szolgáltatásokat igénybe vevôket kívántuk elérni. A kutatási kérdések megválaszolásához többváltozós statisztikai módszereket használtunk. Elsô lépésben faktorelemzést hajtottunk végre, vagyis elvégeztük az innovativitás területeinek azonosítását. A második lépésben varianciaelemzés segítségével teszteltük az innováció egyes területeinek alakulását szociodemográfiai ismérvek, illetve az igénybevételi szokások alapján. A szociodemográfiai ismérvek közül az életkort és a családi 
Tudományos múhely

3. táblázat: A minta demográfiai összetétele

\begin{tabular}{|c|c|c|c|c|c|}
\hline \multirow{2}{*}{ Lakóhely } & falu & kisváros & nagyváros & megyeszékhely & fốváros \\
\hline & $15,7 \%$ & $64,7 \%$ & $8,8 \%$ & $8,4 \%$ & $2,4 \%$ \\
\hline \multirow{4}{*}{$\begin{array}{l}\text { Gazdasági } \\
\text { aktivitás }\end{array}$} & $\begin{array}{c}\text { aktív } \\
\text { szellemi }\end{array}$ & aktív fizikai & tanuló & nyugdíjas & munkanélküli \\
\hline & $28,9 \%$ & $34,1 \%$ & $30,0 \%$ & $4,8 \%$ & $2,4 \%$ \\
\hline & eltartott & egyéb & & & \\
\hline & $1,2 \%$ & $4,4 \%$ & & & \\
\hline \multirow[t]{2}{*}{$\begin{array}{l}\text { Családi élet- } \\
\text { ciklus }\end{array}$} & $\begin{array}{l}\text { fiatal egye- } \\
\text { dülálló }\end{array}$ & $\begin{array}{c}\text { kapcsolatban } \\
\text { élő gyermek } \\
\text { nélkül }\end{array}$ & $\begin{array}{c}\text { kapcsolat- } \\
\text { ban élő } \\
10 \text { év alatti } \\
\text { gyermekkel }\end{array}$ & $\begin{array}{c}\text { kapcsolatban } \\
\text { éló } 10 \text { év feletti } \\
\text { gyermekkel }\end{array}$ & $\begin{array}{l}\text { idôs egyedül- } \\
\text { álló }\end{array}$ \\
\hline & $36,1 \%$ & $24,1 \%$ & $15,3 \%$ & $22,1 \%$ & $1,2 \%$ \\
\hline \multirow[t]{2}{*}{ Anyagi helyzet } & $\begin{array}{c}\text { anyagi } \\
\text { gondokkal } \\
\text { küzd }\end{array}$ & $\begin{array}{l}\text { éppen csak } \\
\text { megél a } \\
\text { fizetéséből }\end{array}$ & $\begin{array}{c}\text { nem } \\
\text { panaszkodik }\end{array}$ & $\begin{array}{l}\text { még spórolni } \\
\text { is tud }\end{array}$ & $\begin{array}{c}\text { kifejezetten } \\
\text { jó anyagi } \\
\text { körülmények } \\
\text { között él } \\
\end{array}$ \\
\hline & $10,0 \%$ & $8,0 \%$ & $43,8 \%$ & $25,7 \%$ & $12,4 \%$ \\
\hline \multirow{2}{*}{$\begin{array}{l}\text { Wellness-szol- } \\
\text { gáltatások igény- } \\
\text { bevételének } \\
\text { gyakorisága }\end{array}$} & $\begin{array}{l}\text { évente } \\
\text { többször }\end{array}$ & $\begin{array}{l}\text { ritkábban, } \\
\text { mint évente }\end{array}$ & & & \\
\hline & $66 \%$ & $34 \%$ & & & \\
\hline \multirow{2}{*}{$\begin{array}{l}\text { Wellnesskiadá- } \\
\text { sok nagysága } \\
\text { éves szinten }\end{array}$} & $\begin{array}{c}100000 \mathrm{Ft} \\
\text { alatt }\end{array}$ & $\begin{array}{c}100001- \\
200000 \mathrm{Ft}\end{array}$ & $\begin{array}{l}200000 \mathrm{Ft} \\
\text { felett }\end{array}$ & & \\
\hline & $59,8 \%$ & $27,3 \%$ & $12,9 \%$ & & \\
\hline
\end{tabular}

Forrás: Saját szerkesztés, $n=249$ fô

életciklust elemezzük, hiszen az egészségturizmus piacán az igénybe vevôk szegmentálását is e szerint végzik.

\section{EREDMÉNYEK}

Az innovációval kapcsolatos attitûd kapcsán 12 állítás került a vizsgálatba. (A skála megbízhatóságát igazoló Cronbach-féle alfa értéke 0,876 , amely alapján a skálánk konzisztens. A faktorelemzés helyességét igazoló mutatók értéke megfeleló, KMO: 0,865, Bartlett: 1242,585, Sig. 0,000). Az elsố faktorba tartoznak a marketingmix-elemekhez tartozó innovációk, mint a fürdóhely kialakítása, az újdonságok - termékek, szolgáltatások - bevezetése, online foglalási és fizetési lehetôségek, kommunikációs meg- oldások: közösségimédia-jelenlét, chatbotok használata, pozitív szájreklám. Az elsô faktor által magyarázott varianciahányad 27,48\%, kezdố sajátértéke 5,17. Mivel itt elsôsorban a termékhez, értékesítéshez és kommunikációhoz kapcsolódó innovációk fontossága jelenik meg, ezért a faktor a marketingújitásokra való fogékonyság elnevezést kapta.

A második faktor az újdonságokra való fogékonyság elnevezést kapta, hiszen az innovációk általános fogyasztói elfogadására vonatkozó attitúdállításokat foglalja magában. A második faktor által magyarázott varianciahányad 21,82\%, kezdô sajátérték 1,43. Az idetartozó változók: A barátaimhoz képest sokkal szívesebben próbálom ki az újdonságokat a wellnesspiacon. Ha egy termék vagy szolgáltatás más, mint a többi 


\section{Tudományos múhely}

a wellness-iparágban, akkor ki kell próbálnom. Fontos számomra, hogy lépést tartsak a technológiai fejlódéssel a wellnessiparágban. Fontos számomra, hogy kipróbáljam az új szolgáltatásokat.

A harmadik faktor csupán két tényezôt tömörít - akciós ár, kedvezményes csomagajánlat -, és mivel az árpolitikára vonatkozik, ezért az árinnovációk elnevezést kapta. A faktor által magyarázott variancia mértéke 14,32\%, kezdô sajátértéke 1,03. A faktorok összetételét, a velük kapcsolatos faktorsúlyokat, valamint egyéb mutatókat a 4. táblázat mutatja.

A faktorelemzés eredménye alapján az elsô kutatási kérdésre adott válasz, hogy az innovativitásnak három területe különíthetố el: marketingújításokra való fogékonyság, újdonságokra való fogékonyság és árinnová- ciók. A létrejött faktorstruktúrát alapul véve a számított átlagok alapján további elemzéseket végeztünk. A vizsgált minta számára az árinnovációk $(4,46)$ a legfontosabbak, illetve a marketingújítások $(3,66)$. Az innovativitás, vagyis az újdonságokra való fogékonyság $(3,40)$ kevésbé meghatározó. A következô lépésben megvizsgáltuk, hogy az egy faktorba tartozó változók átlagértékei hogyan alakulnak az egyes fontosnak vélt háttérváltozók alapján képzett almintákban, nevezetesen, a válaszadó életkora, családi életciklusa, wellness-szolgáltatások igénybevételi gyakorisága és az éves kiadások nagysága alapján elkülönített csoportokban. A kapcsolatokat varianciaelemzés lefuttatásával teszteltük.

Az eredmények alapján megállapítható, hogy a vizsgált változók esetében szignifikáns összefüggések mutathatók ki:

\section{4. táblázat: Az innovációk területei}

\begin{tabular}{|c|c|c|}
\hline Változók: Fontos számomra a wellness-Szolgáltatások kapcsán & Faktorsúly & Faktor \\
\hline a hely kialakítása & 0,756 & \multirow{6}{*}{$\begin{array}{l}\text { 1. marketing- } \\
\text { újításokra való } \\
\text { fogékonyság } \\
(27,48 ; 0,82 ; 6)\end{array}$} \\
\hline az újdonságok (termékek, szolgáltatások) bevezetése & 0,749 & \\
\hline $\begin{array}{l}\text { az új értékesítési lehetôségek bevezetése (online foglalás és } \\
\text { fizetés) }\end{array}$ & 0,725 & \\
\hline a közösségimédia-jelenlét & 0,683 & \\
\hline a chatbotok alkalmazása & 0,596 & \\
\hline $\begin{array}{l}\text { hogy az újdonságokkal kapcsolatos tapasztalataimat másokkal } \\
\text { is megosszam }\end{array}$ & 0,577 & \\
\hline $\begin{array}{l}\text { A barátaimhoz képest sokkal szívesebben próbálom ki az új- } \\
\text { donságokat a wellnesspiacon. }\end{array}$ & 0,797 & \multirow{4}{*}{$\begin{array}{l}\text { 2. újdonságokra } \\
\text { való fogékonyság } \\
(21,82 ; 0,81 ; 4)\end{array}$} \\
\hline $\begin{array}{l}\text { Ha egy termék vagy szolgáltatás más, mint a többi a wellness- } \\
\text { iparágban, akkor ki kell próbálnom. }\end{array}$ & 0,789 & \\
\hline $\begin{array}{l}\text { Fontos számomra, hogy lépést tartsak a technológiai fejlódéssel } \\
\text { a wellnessiparágban. }\end{array}$ & 0,699 & \\
\hline Fontos számomra, hogy kipróbáljam az új szolgáltatásokat. & 0,667 & \\
\hline Fontos számomra a wellness-szolgáltatások kapcsán az akciós ár. & 0,874 & \multirow{2}{*}{$\begin{array}{l}\text { 3. árinnovációk } \\
(14,32 ; 0,77 ; 2)\end{array}$} \\
\hline $\begin{array}{l}\text { Fontos számomra a wellness-szolgáltatások kapcsán a kedvez- } \\
\text { ményes csomagár, csomagajánlat. }\end{array}$ & 0,851 & \\
\hline
\end{tabular}

Megjegyzés: Módszer: Fókomponens-elemzés, Forgatás: Varimax. A faktorok mögötti elsó szám az adott faktor által magyarázott variancia, a második az adott skála Cronbach-alfája, a harmadik a faktorhoz tartozó változók száma.

Forrás: Saját szerkesztés 


\section{Tudományos múhely}

- Életkor alapján a marketingújításokra való fogékonyságnál és az árinnovációknál találtunk szignifikáns eltéréseket. A középkorúak számára fontosabbak a marketingújítások, csakúgy, mint az árinnovációk.

- Családi életciklus kapcsán elmondható, hogy az árinnovációk a gyermek nélküli párok és gyermekes házaspárok számára a leglényegesebb. Az idôs egyedülállók számára a legkevésbé, bár ók voltak azok, akik egyik típusú innovációt sem tartották különösen fontosnak.

- Igénybevételi gyakoriság szempontjából megállapítható, hogy azok, akik évente többször is igénybe vesznek wellness-szolgáltatásokat, innovatívabbak, fogékonyabbak a marketingújításokra és általában véve az újdonságokra.

- Az éves wellnesskiadásokat elemezve, szintén az elôbb említett dimenzióknál találunk szignifikáns eltéréseket. Minél többet költ valaki egy évben wellness típusú egészségturizmusra, annál fontosabbnak tartja a marketingmix valamely eleméhez kapcsolódó innovációkat, és annál inkább fogékony ezekre az újdonságokra (5. táblázat).

A második kutatási kérdésre adott válasz, hogy az életkor befolyásolja a marketingújításokra való fogékonyságot és az árinnovációk fontosságát, a családi életciklus pedig az utóbbit. A középkorúak fogékonyak leginkább a marketingújításokra, illetve az árinnovációkra. Az árakkal kapcsolatos újdonságok leginkább a párkapcsolatban élóket és a gyerekes családokat vonzzák, legkevésbé pedig az idôs egyedülállókat.

A harmadik kutatási kérdésre adott válasz, hogy az igénybevétel gyakorisága és a kiadások nagysága befolyásolja a fürdóvendégek marketingújításokra és általában az újdonságokra való fogékonyságát. A fürdôszolgáltatásokat gyakrabban igénybe vevôk és az éves szinten magasabb öszszeget költôk számára fontosabbak a marketingújítások, és ôk fogékonyabbak is az innovációkra.

\section{KövETKEZTETÉSEK}

A fürdoolétesítmények jövôbeni fejlesztési tervei komplex, az adott településsel összehangolt, lokális egyediséget hangsúlyozó szemléletmódot igényelnek. A fürdô mint kínálati elem összekapcsolható adott desztináció további kínálati elemeivel (kultúra, történelem, bor, gasztronómia, természet, sport stb.). Ezek összehangolt fejlesztése hozzájárul a tartózkodási idô meghosszabbításához, a vendégek fajlagos költésének növekedéséhez (Printz-Markó, 2008b). A nemzeti turisztikai fejlesztési stratégia hangsúlyozza, hogy egy fürdőhely fejlesztésénél elengedhetetlen a megfelelô szálláshelykínálat, a helyi termékalapú élményláncok kialakítása, továbbá a szolgáltatások és a meglévô infrastruktúra minốségi és mennyiségi fejlesztése.

A wellness- és rekreációs szolgáltatásokat igénybe vevốk számára különösen fontosak az ár és a további marketingmixelemekhez kapcsolódó innovációk. A fürdôvendégek kevésbé innovatívak, nem annyira fogékonyak az újdonságokra, különösen igaz ez az idôsebb (55 év feletti) vendégekre és az idôsebb egyedülállókra. A fiatalok és a kisgyerekes családok, illetve a középkorú párok számára fontos az innováció, a szolgáltatás kiválasztásakor döntố szempont lehet számukra akár a termék vagy szolgáltatás területén nyújtott újítások, vagy a digitális innovációk, legyen szó az értékesítésrôl vagy a reklámozásról.

Így számos olyan innováció létezik, amit érdemes lenne a hazai fürdôknek is kihasználni, hiszen versenyelônyt jelenthet számukra. Az árak kétségkívül jelentôs vonzerôvel bírnak, hiszen az akciók, kedvezményes csomagajánlatok mindenki számára fontosak, különösen a középkorúak és a családosok számára. A fürdốk törekedhetnének az ár típusú promóciók változatos alkalmazására, a nyílt és burkolt árengedményeken át a mennyiségi kedvezményen keresztül a húségprogramokig. Ezenkívül a többi marketingmixelemre is érdemes nagy figyelmet fordítani. Különösen a direktmarketing- 
Tudományos múhely

5. táblázat: Az innovációk területeinek fontossága demográfiai ismérvek és igénybevételi szokások alapján

\begin{tabular}{|c|c|c|c|c|}
\hline & & $\begin{array}{c}\text { Marketing- } \\
\text { újításokra való } \\
\text { fogékonyság } \\
(\mathbf{3 , 6 6 )}\end{array}$ & $\begin{array}{c}\text { Újjdonságokra } \\
\text { való } \\
\text { fogékonyság } \\
(3,40) \\
\end{array}$ & $\begin{array}{c}\text { Árinnovációk } \\
\qquad(4,46)\end{array}$ \\
\hline \multirow{4}{*}{ Életkor } & fiatal (15-34 év) & 3,59 & 3,36 & 4,36 \\
\hline & középkorú (35-54 év) & 3,86 & 3,53 & 4,63 \\
\hline & $55+$ & 3,50 & 3,25 & 4,53 \\
\hline & F statisztika (sig) & $4,02(0,01)$ & nem szignifikáns & 3,91 $(0,02)$ \\
\hline \multirow{6}{*}{$\begin{array}{l}\text { Családi } \\
\text { életciklus }\end{array}$} & fiatal egyedülálló & 3,58 & 3,37 & 4,27 \\
\hline & $\begin{array}{l}\text { kapcsolatban élố gye- } \\
\text { rek nélkül }\end{array}$ & 4,22 & 3,41 & 4,66 \\
\hline & $\begin{array}{l}\text { kapcsolatban élő } 10 \text { év } \\
\text { alatti gyerekkel }\end{array}$ & 3,70 & 3,50 & 4,51 \\
\hline & $\begin{array}{l}\text { kapcsolatban éló } 10 \text { év } \\
\text { feletti gyerekkel }\end{array}$ & 3,76 & 3,48 & 4,63 \\
\hline & idôs egyedülálló & 2,55 & 2,66 & 3,66 \\
\hline & F statisztika (sig) & nem szignifikáns & nem szignifikáns & $3,68(0,00)$ \\
\hline \multirow{3}{*}{$\begin{array}{l}\text { Igénybe- } \\
\text { vételi } \\
\text { gyakoriság }\end{array}$} & Évente többször & 3,78 & 3,52 & 4,52 \\
\hline & Ritkábban, mint évente & 3,42 & 3,16 & 4,34 \\
\hline & F statisztika (sig) & $13,72(0,00)$ & $11,15(0,00)$ & nem szignifikáns \\
\hline \multirow{4}{*}{$\begin{array}{l}\text { Éves } \\
\text { kiadások }\end{array}$} & $100000 \mathrm{Ft}$ alatt & 3,56 & 3,27 & 4,39 \\
\hline & $100001-200000 \mathrm{Ft}$ & 3,70 & 3,47 & 4,53 \\
\hline & $200001 \mathrm{Ft}$ felett & 4,03 & 3,84 & 4,65 \\
\hline & F statisztika (sig) & $5,47(0,00)$ & $6,90(0,00)$ & nem szignifikáns \\
\hline
\end{tabular}

Forrás: Saját szerkesztés, $n=249$ fô

aktivitásokra, hiszen a fürdôszolgáltatásokat gyakrabban és ennek megfelelően magasabb összegben igénybe vevôk fogékonyabbak az újdonságokra és a marketinginnovációkra. Az ô tájékoztatásuk, hírlevélben történố informálásuk bármilyen típusú újításról lényeges lehet, akár a fürdôk, akár a fürdôszövetség részérôl.

A mélyinterjúk során jegyzeteket készítettünk, amelyeket a kérdôívvel együtt kódoltunk a visszakereshetôség érdekében. A kutatás általánosíthatósága korlátozott, ugyanis anyagi és idôbeli korlátok miatt alacsony a kérdôív elemszáma, továbbá a kutatás lebonyolítása és az eredmények feldolgozása, kiértékelése között eltelt idó, valamint a koronavírus okozta világjárvány és a szigorítások miatt a vélemények más megvilágításba kerülhettek. Mindennek ellenére a mélyinterjú és a kérdôív igazodik kutatási célunkhoz. Kutatómunkánk egyfajta feltáró elemzésnek is tekinthetô. Az eredmények pontos leírása révén a kutatás több területen is hasznosítható. Kutatásunk jövốbeli iránya, hogy kérdốívünket egy kiválasztott fürdô (mintafürdô) vendégei körében lebonyolítsuk. Kutatómunkánk tartalma fürdőüzemeltetố szakemberek, 


\section{Tudományos múhely}

szakmai szervezetek számára felhasználható, egyfajta kiindulási pontnak tekinthetô jövőbeni marketingakciók, szolgáltatási és termékfejlesztési tervek, árpromóciók elôkészítéséhez.

\section{Összegzés}

Az egészségturizmus kreatív és kihívásokkal teli ágazatként jellemezhetô. Egyik fő mozgatórugójának az intenzív innováció tekinthetô. Kutatómunkánk vonatkozásában megállapítható, hogy az ágazatban múködő hazai fürdôk az innováció területén széles spektrumú lehetôséggel rendelkeznek, mint például az igazi egyediségek, karakterek feltárása.

Kutatómunkánk során arra a következtetésre jutottunk, hogy a fürdólétesítmények innovációs folyamatát számos tényezô befolyásolja. Innovációs terükben nagy jelentôsége van a természeti adottságnak, a természetes gyógytényezônek, a célcsoportnak és az üzemeltetônek, személyzetnek. Az üzemeltetô gazdasági hasznossága mellett fontos egyfajta társadalmi hasznosság elérése is, amely értelmezhetô a jó egészségi állapot megőrzéseként, visszanyeréseként, vagy a fürdóélmény (spaélmény) átéléseként.

Kutatási eredményeink alapján a fürdőkhöz kapcsolódó turizmus gazdaságunk innovációs potenciálját jelenti. Kiemelten szükséges foglalkozni innovációs tartalékaik feltárásával. Mivel a fürdôvendég nemcsak a fürdó „fogyasztója”, hanem az adott fürdőtelepülésé is, ezért az ágazat jövőjét folyamatosan változó, a helyi értékeket és érdekeket védő, a fenntartható fejlődés elveit szem elótt tartó turizmustípusnak prognosztizáljuk. Eredményeink hasznosíthatók fürdőfejlesztési tervekhez, hozzájárulva az adott fürdőlétesítmény és fürdôtelepülés egyediségének, arculatának kialakításához. Mindezt támogathatja a felsôoktatási, a vállalati és a kutatási szféra közötti erôsebb kapcsolat.

\section{FELHASZNÁLt IRODALOM}

Amoiradis, Christos (2019): A Theoretical Approach to Sustainable Tourism Marketing. Economics and Law, Vol. 1, No. 2, 1-7.

Árpási Zoltán (2012): Wellness turisztikai szolgáltatások fejlesztésének lehetôségei a Dél-alföldi régióban. PhD-értekezés. Szent István Egyetem, Gazdálkodás- és Szervezéstudományok Doktori Iskola, Gödölló.

Budai Zoltán - Székács Orsolya (2004): A magyar egészségturisztikai kínálat alakítása a különbözô célcsoportok igényei szerint. In: Aubert Antal Csapó János (szerk.): Egészségturizmus. PTE TTK Földrajzi Intézet, Pécs, 137-144.

Chikán Attila (2008): Vállalatgazdaságtan. Aula Kiadó, Budapest.

Darabos Ferenc - Happ Éva - Ivancsóné Horváth Zsuzsanna - Printz-Markó Erzsébet (2018): Nyúl település turisztikai marketingstratégiája 2018-2026. Széchenyi István Egyetem Kautz Gyula Gazdaságtudományi Kar Turizmus Tanszék, Gyôr.

Global Wellness Institute (2018): Global Wellness Economy Monitor. https://globalwellnessinstitute. org/industry-research/2018-global-wellness-economy-monitor/ (Letöltés: 2020. július 8.).

Global Wellness Institute (2020): The 2020 Global Wellness Trends. www.globalwellnesssummit. com/2020-global-wellness-trends/ (Letöltés: 2020. július 9.).

Gonda Tibor - Spiegler Patrícia (2012): A turisztikai klaszterek szerepe a regionális marketingben. Marketing $\mathcal{E}$ Menedzsment, 46. évf., 1-2. sz., $15-25$.

Gyôri Ferenc - Hézsôné Böröcz Andrea - Kiss Gábor - Lehmann-Dobó Andrea - Meszlényi-Lenhart Emese - Balogh László (2013): Wellness, sport és egészségturizmus. Szegedi Tudományegyetem JGYPK, Szeged.

Happ Éva - Keller Veronika (2020): Marketingkommunikáció a turizmusban. Széchenyi István Egyetem, Gyôr.

Haywood, K. Michael (1990): Revising and Implementing the Marketing Concept As It Applies to Tourism. Tourism Management, Vol. 11, No. 3, 195-204, https://doi.org/10.1016/0261-5177(90)90042-8.

Horváth Dóra - Bauer András (2016): Marketingkommunikáció. Stratégia, új média, fogyasztói részvétel. Akadémiai Kiadó, Budapest, https://doi. org/10.1556/9789630597227. 


\section{Tudományos múhely}

Katona József (2006): Az innováció értelmezése a 2005. évben kiadott Oslo kézikönyv harmadik kiadása alapján. Magyar Innovációs Szövetség, Budapest.

Lốrincz Katalin - Priszinger Krisztina - Raffay Ágnes (2014): Befürdünk? Hazai egészségturisztikai desztinációk turizmusirányítási gyakorlata. In: Martyin Zita - Vedrédi Katalin (szerk.): Cooling Cubes - Fürdôfejlesztési Stratégiák és Hálózatok. Konferenciakötet, Szeged, 15-31.

Magyar Fürdôszövetség (2019a): Trendriport 2019. A hazai fürdôágazat teljesítményének vizsgálata 2019. I. félév. www.furdoszovetseg.hu/wp-content/uploads / 2019/08/furdok-trendriport-2018-2019-ifelev.pdf (Letöltés: 2019.október 15.).

Magyar Fürdôszövetség (2019b): Magyar Fürdôinnovációs Díj 2019. www.furdoszovetseg.hu/magyar-furdoinnovacios-dij-2019/ (Letöltés: 2020. július 9.)

Magyar Turisztikai Ügynökség (2017): Nemzeti Turizmusfejlesztési Stratégia 2030. Magyar Turisztikai Ügynökség, Budapest.

Magyar Turizmus Zrt. (2009): Marketingstratégia 2010-2012. http://docplayer.hu/1688022-Marketingstrategia-2010-2012.html (Letöltés: 2020. július 1.).

Middleton, Victor T. C. - Hawkins, Rebecca (1998): Sustainable Tourism. A Marketing Perspective. Butterworth-Heineman, Oxford.

MTI (2019a): Ezek a legjobb fürdôk most Magyarországon: itt a lista! Hellovidek.hu, www.hellovidek.hu/utazas/2019/11/19/ezek-a-legjobb-furdok-most-magyarorszagon-itt-a-lista (Letöltés: 2020. július 1.).

MTI (2019b): Elérték az innováció hullámai a magyar fürdőket. Mandiner, https://makronom. mandiner.hu/cikk/20191119_elertek_az_innovacio_hullamai_a_magyar_furdoket (Letöltés: 2020. július 1.).

MTI (2020): KSH: a hazai gyógyfürdôkrôl és a fôváros turizmusáról. Turizmus Online, http:// turizmusonline.hu/belfold/cikk/ksh__a_hazai_gyogyfurdokrol_es_a_fovaros_turizmusarol (Letöltés: 2020. július 22.).

Németh István (2002): A hévízgazdálkodás, a gyógyés termálfürdőügy irányai a Magyar Hidrológiai Társaság XIX. Országos Vándorgyúlése elôadásainak tükrében. Balneológia, Gyógyfürdốügy, Gyógyidegenforgalom, 23. évf., 1-2. sz., 37-46.

Piskóti István (2007): Innovációmarketing - marketinginnováció. Miskolci Egyetem, Miskolc.

Printz-Markó Erzsébet (2007): Klaszterizáció: „glokalitás"? In: Szentes Balázs (szerk.): Európai integráció - elvek és döntések. Gazdasági fejlôdés Európában. II. Pannon Gazdaságtudományi Konferencia, Pannon Egyetem, Veszprém, 189-195.

Printz-Markó Erzsébet (2008a): European Spa World - Jövố a kooperációban. In: Lơrincz Ildikó (szerk.): XI. Apáczai Napok 2007 Nemzetközi Tudományos Konferencia. Tanulmányok: Értékôrzés és értékteremtés. NyME-AK, Gyôr, 517-525.

Printz-Markó Erzsébet (2008b): Mikroelemek hatása a mosonmagyaróvári gyógyvízben. Acta Agronomica Óváriensis, 50. évf., 1. sz., 183-189.

Printz-Markó Erzsébet (2019): Fürdômenedzsment. Tananyagfejlesztés, Széchenyi István Egyetem Kautz Gyula Gazdaságtudományi Kar Turizmus Tanszék, Győr.

Rátz Tamara (2004): Zennis és Lomi Lomi, avagy új trendek az egészségturizmusban. In: Aubert Antal - Csapó János (szerk.): Egészségturizmus. Fôiskolai jegyzet, PTE TTK Földrajzi Intézet, Pécs, 46-65.

Schalev, Edith - Morwitz, Vicki G. (2012): Influence via Comparison-Driven Self-Evaluation and Restoration: The Case of Low-Status Influencer. Journal of Consumer Research, Vol. 38, No. 5, 964980, https://doi.org/10.1086/661551.

Schumpeter, Joseph A. (1939): Business Cycles. McGraw Hill, New York-London.

Smith, Melanie - Puczkó László (2010): Egészségturizmus: gyógyászat, wellness, holisztika. Akadémiai Kiadó, Budapest.

Spiegler Patrícia (2009): A turisztikai imázs és a területi identitás jelentôsége a térségi marketingben. Területfejlesztés és Innováció, 3. évf., 1. sz., 16-23.

Szabó Zoltán (2015): A gyógyvízre alapozott fürdôváros-fejlesztések lehetôségei. PhD-értekezés, Kaposvári Egyetem, Gazdaságtudományi Kar Kereskedelmi és Marketing Tanszék Doktori Iskola, Kaposvár.

Turizmus.com (2019): Trendriport a fürdôkrốl: emelkedtek a bevételek. Turizmus.com, https:// turizmus.com/desztinaciok/trendriport-a-furdok-teljesitmenyerol-1163544 (Letöltés: 2020. július 22.).

Turizmus Panoráma Bulletin (2015): Befürdünk, vagy sikerben fürdünk? Turizmus Panoráma Bulletin, 2015/230., http://m.turizmus.com/fokusz/ befurdunk-vagy-sikerben-furdunk-1132746 (Letöltés: 2019. október 15.).

Vámos Éva (2019): Hévíz, Mórahalom, Zalakaros a Magyar Fürdôinnovációs Díj nyertesei. Turizmus.com, 


\section{Tudományos múhely}

https://turizmus.com/utazas-kozlekedes/heviz-morahalom-zalakaros-a-magyar-furdoinnovacios-dij-nyertesei-1167301 (Letöltés: 2020. július 9.).

Várhelyi Tamás (2012): A zászlóshajó navigációs nehézségei. Világtrendek az egészségturizmusban. Turizmus Trend, 3. sz., 36-37.
Vazquez-Illá Navarro, Javier (2014): How Innovation Shapes the Spa Industry and Determines its Evolution. Global Journal of Management and Business Research, Vol. 14, No. 2.

Walle, Alf H. (1998): Cultural Tourism: A Strategic Focus. Westview Press, Boulder. 